J. Lake Sci.(湖泊科学), 2008, 20(6): 733-740

http://www.jlakes.org. E-mail: jlakes@niglas.ac.cn

(C2008 by Journal of Lake Sciences

\title{
长江流域水汽收支的时空变化与环流特征
}

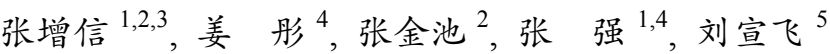

(1: 中国科学院南京地理与湖泊研究所, 南京 210008)

(2: 南京林业大学江苏省林业生态工程重点实验室, 南京 210037)

(3: 中国科学院研究生院, 北京 100049)

(4: 中国气象局气候研究开放实验室, 北京 100081)

(5: 无锡工艺职业技术学院, 无锡 214220)

摘 要: 通过分析 1961-2005 年长江流域水汽收支的时空变化及环流特征, 发现: 1)长江流域春季、秋季、冬季和年均水汽收 支下降，而夏季增加; 长江上游除夏季外均变化显著，中下游则只有春季、夏季和秋季变化显著; 2)长江中下游各季节及年水 汽收支与降水的关系都通过了显著性检验，其中夏季关系最好，而长江上游只有春季和秋季通过显著性检验; 3)夏季长江流 域水汽输送下降, 但水汽收支却增加, 可能与东亚夏季风减弱有关, 而东亚夏季风的减弱可能与东亚大陆上空低层大气位势 高度显著增强有关.

关键词: 水汽收支; 趋势分析; 大气环流; 长江流域

\section{Spatial-temporal properties of moisture budget and associated large-scale circulation in the Yangtze River Basin}

\author{
ZHANG Zengxin ${ }^{1,2,3}$, JIANG Tong ${ }^{4}$, ZHANG Jinchi ${ }^{2}$, ZHANG Qiang ${ }^{1,4}$ \& LIU Xuanfei ${ }^{5}$ \\ (1: Nanjing Institute of Geography and Limnology, Chinese Academy of Sciences, Nanjing 210008, P.R.China) \\ (2: Jiangsu Key Laboratory of Forestry Ecological Engineering, Nanjing Forestry University, Nanjing 210037, P.R.China) \\ (3: Graduate School of the Chinese Academy of Sciences, Beijing 100049, P.R.China) \\ (4: Laboratory for Climate Studies, National Climate Center, China Meteorological Administration, Beijing 100081, P.R.China) \\ (5: Wuxi Institute of Arts and Technology, Wuxi 214220, P.R.China)
}

Abstract: Trends of moisture budget were explored during 1961 to 2005, using simple linear regression method, in the Yangtze River basin, China. The results indicated that: 1) the moisture budget decreased in winter, spring and fall, but increased in summer. The trend of moisture budget was significant except for summer in the upper Yangtze River basin. While significant trends could be identified in moisture budget in spring, summer and autumn in the middle and lower Yangtze River basin; 2) the correlation between moisture budget and precipitation was significant related at all of the seasons in the middle and lower Yangtze River basin, and was significant related in spring and autumn in the upper Yangtze River basin; 3) the summer moisture transport was in significant decreasing trend in the Yangtze River basin, which might be closely associated with lower layer geopotential height. The summer circulation showed increasing continental high over north China, which weakened the southwesterly summer monsoon and limits propagation of the summer monsoon to north China, resulting in more water vapor budget in the Yangtze River basin and less in north China.

Keywords: Moisture budget; trend; circulation; the Yangtze River basin

近 50 年来, 随着全球气候变暖, 水循环的加快, 长江流域降水也发生了明显变化: 1961-2005 年, 长江 流域夏季和冬季降水显著增加, 而春季和秋季降水明显减少; $1990 \mathrm{~s}$ 成为近 50 年长江流域夏季和冬季降水

* 中国气象局气候变化专项(CCSF2007-35)、淮河流域开放研究基金(HRM200708)“十一五”国家林业科技支撑项目 (2006BAD03A1601)和江苏省自然科学基金(BK2006251)联合资助. 2008-01-10 收稿. 2008-05-12 收修改稿; 张增信, 男, 1977 年生, 博士研究生; E-mail: zhangzengxin77@yahoo.com.cn. 
最多, 秋季降水最少时期; 但长江上游和中下游地区的降水有明显的地区差异, 上游年降水下降显著, 而中下游年降水却在增加 ${ }^{[1-5]}$. 长江流域径流也有明显变化, 冬季、夏季径流增加, 春季、秋季径流减少, 上游宜昌站年径流在下降，而下游大通站年径流在增加，特别是年最大径流量变化更是如此 ${ }^{[6-7]}$.

长江流域是欧亚大陆上空水汽输送的主要通道之一, 长江流域上空水汽年输人量中, 有 $28.2 \%$ 形成降水, $71.8 \%$ 形成过境水流出境外, 年总蒸发量中, $14.1 \%$ 形成降水重返陆地, 年总降水量中, $93.5 \%$ 是境外输人的水 汽形成的, $6.5 \%$ 是流域内蒸发的水汽形成的, 从而可以看出水汽收支是影响长江流域降水的最重要因素 ${ }^{[8]}$.

陈隆勋等指出, 中国大陆夏季降水的水汽属于外界输送进入的主要来自南海, 其次是孟加拉湾的西 南季风, 再次是副热带高压的东南季风[9]. 长江上游的水汽, 夏季主要来源于孟加拉湾和南海, 秋季主要 来源于西太平洋, 而长江中下游地区主要来源于孟加拉湾和华南 ${ }^{[10-11]}$. Yasunari 等对季风区水汽收支的研 究指出水汽输送通量及其散度取决于大气环流背景, 并有非常明显的区域性和季节性 ${ }^{[12]}$. 苗秋菊等利用 “箱体”模型边界的整层水汽输送特征描述长江流域梅雨带水汽收支总体效应, 揭示了长江流域洪涝过程 上游高原周边关键区水汽输送不同分量间的“转换”特征, 并且发现区域汽收支与夏季降水关系很好 ${ }^{[13]}$. 赵瑞霞等用实测资料计算了长江流域的水分平衡, 并全面评估 NCAR/NCEP 资料对长江流域水分循环的 描述能力, 结果认为: 季节循环方面, NCAR/NCEP 中长江流域由平均流输送所造成的水汽辐合及大气含 水量的季节循环均与实际接近; 年际变化方面, 由平均流输送造成的水汽辐合、总水汽辐合及大气可降 水量的年际变化均与对应实测要素有较好的一致性, 总水汽辐合与实测降水的年际变化也比较一致, 可 以用于这些要素年际变化的以及水汽辐合对于降水年际变化贡献的研究 ${ }^{[14]}$.

大气中的水汽收支与大气环流有着密切的内在联系, 两者作为能量和水分循环过程的重要一环对区 域水分平衡起着至关重要的作用, 大气中的水汽虽仅占 $1 \%-3 \%$, 但却是旱涝灾害的直接驱动因子 ${ }^{[8]}$. 正 确估计水汽收支对于大气环流形成和演变以及进一步理解天气和气候变化及水文循环过程具有重要意义, 此问题多年来备受国内外水文学家和气象学家的广泛关注 ${ }^{[15-20]}$. 长江流域水汽输送不仅年际、季节变化 突出, 而且上游和中下游水汽输送的空间差异也非常大. 因而, 要从机理上分析长江流域降水、径流等变 化的原因, 就需要分析长江流域水汽收支的时空变化及对应的环流特征.

\section{1 资料与方法}

\section{1 资料}

本文使用的资料主要有: (1)1961-2005 年 NCEP/NCAR 再分析资料中逐日的纬向风 $(u)$ 、经向风 $(v)$ 、 比湿 $(q)$ 及地面气压 $\left(p_{s}\right)$ 等资料; (2)1961-2005 年中国气象局提供的 1961-2005 年长江流域 147 个气象站的 日降水资料.

整层大气水汽通量 $Q$ (垂直积分的水汽通量)的计算方式如下:

纬向水汽输送通量:

$$
Q_{\mathrm{u}}(x, y, t)=\frac{1}{g} \int_{p}^{p_{s}} q(x, y, p, t) u(x, y, p, t) \mathrm{d} p
$$

经向水汽输送通量:

$$
Q_{\mathrm{v}}(x, y, t)=\frac{1}{g} \int_{p}^{p_{s}} q(x, y, p, t) v(x, y, p, t) \mathrm{d} p
$$

式中, $Q$ 单位为 $\mathrm{g} /(\mathrm{cm} \cdot \mathrm{s}), p_{s}$ 为地表面气压, $p$ 取值为 $300 \mathrm{hPa}, q$ 为比湿, $g$ 为重力加速度. 用“箱体”模型描述 长江流域水汽收支季节变化特征, 分别定义 $\left(25^{\circ}-35^{\circ} \mathrm{N}, 100^{\circ}-110^{\circ} \mathrm{E}\right) 、\left(25^{\circ}-35^{\circ} \mathrm{N}, 110^{\circ}-120^{\circ} \mathrm{E}\right)$ 区域为长江 上游和长江中下游地区整层水汽收支“箱体”模型计算范围, 长江上游和中下游地区“箱体”模型边界水汽 收支效应由下式计算 ${ }^{[21-22]}$ :

$$
\begin{gathered}
Q_{\mathrm{W}}=\sum_{\varphi_{1}}^{\varphi_{2}} Q_{\mathrm{u}}\left(\lambda_{1}, y, t\right) \\
Q_{\mathrm{E}}=\sum_{\varphi_{1}}^{\varphi_{2}} Q_{\mathrm{u}}\left(\lambda_{2}, y, t\right)
\end{gathered}
$$




$$
\begin{aligned}
Q_{\mathrm{S}} & =\sum_{\lambda_{1}}^{\lambda_{2}} Q_{\mathrm{v}}\left(x, \varphi_{1}, t\right) \\
Q_{\mathrm{N}} & =\sum_{\lambda_{1}}^{\lambda_{2}} Q_{\mathrm{v}}\left(x, \varphi_{2}, t\right) \\
Q_{\mathrm{T}} & =Q_{\mathrm{W}}-Q_{\mathrm{E}}+Q_{\mathrm{S}}-Q_{\mathrm{N}}
\end{aligned}
$$

式中, $Q_{\mathrm{W}}, Q_{\mathrm{E}}, Q_{\mathrm{S}}, Q_{\mathrm{N}}$ 分别为长江流域西、东、南、北 4 个边界水汽收支; $Q_{\mathrm{T}}$ 为区域边界总体水汽收支; $\lambda_{1}$, $\lambda_{2}, \varphi_{1}, \varphi_{2}$ 分别为各边界对应的纬度和经度.

\section{2 方法}

本文采用的研究方法主要有一元线性回归及相关系数法, 文中显著性检验都为 $95 \%$ 的置信度水平. 研究数据的均一性采用计算 Von Neumannratio $(N)$, Cumulative deviations $\left(Q / n^{-0.5}, R / n^{-0.5}\right)$, Bayesian procedures $(U, A)$ 等三种统计量的方法. 分别对长江流域 147 个气象站降水数据做均一性检验, 检验结果 表明所分析序列在 $95 \%$ 的置信度水平上是具有一致性 ${ }^{[23]}$.

\section{2 长江流域水汽收支特征}

\section{1 长江流域水汽收支的长期变化}

水汽收支是一个地区某一段时间内水汽的净收人, 它的多少直接影响着流域降水和流量的多塞, 决 定了流域的旱涝情况，因而，大气水分循环对于流域水分循环起着至关重要的作用. 长江上游, 夏季水 汽收支最高, 其次为秋季和春季, 冬季最少; 而长江中下游地区最高出现在夏季, 其次是春季和冬季, 秋 季最少. 冬季, 长江上游和中下游水汽收支都出现下降, 其中上游下降显著, 中下游未通过显著性检验; 春季, 上游和中下游水汽收支都下降显著, 中下游下降趋势略高于上游地区. 夏季, 上游和中下游地区 水汽收支都出现增加, 中下游地区增加显著, 而上游只有微弱增加; 秋季, 水汽收支都出现下降, 而且下 降显著, 长江中下游地区下降幅度超过上游地区(图 1). 长江上游和中下游地区年水汽收支都出现下降, 上游水汽收支下降显著, 中下游地区水汽收支也出现下降, 但未通过显著性检验.

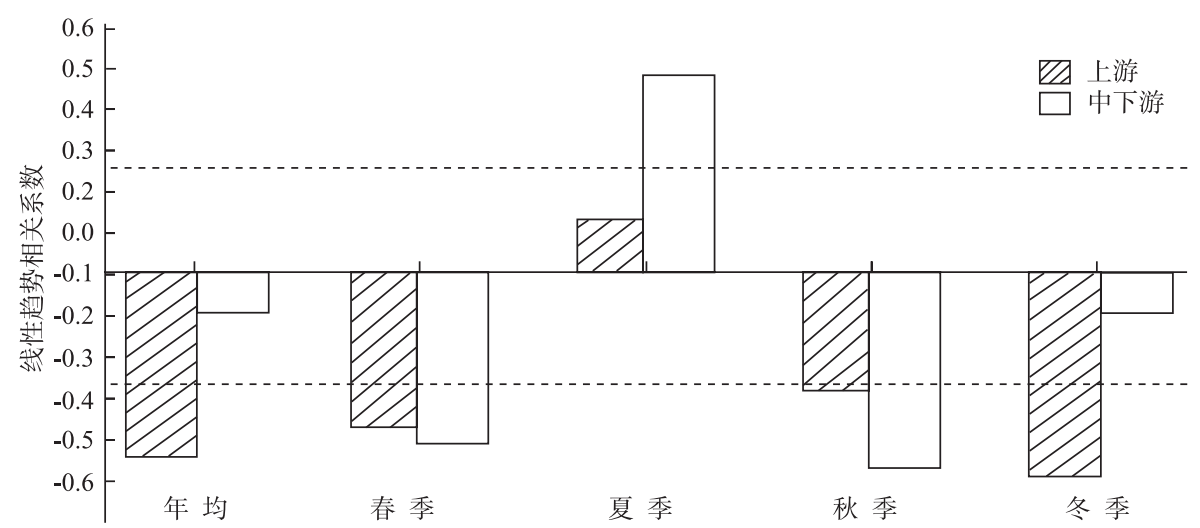

图 1 1961-2005 年长江上游和中下游水汽收支的线性趋势 (虚线表示通过 $95 \%$ 的显著性检验)

Fig.1 Linear trends of water vapor budget in the Yangtze River basin (the dash lines denote the $95 \%$ significance level)

\section{2 长江流域水汽边界输送与水汽收支}

长江流域东边界总的水汽收支全年均为西风输出, 将水汽带出流域, 西边界全年为西风输人, 但水 汽输人量很小; 南边界全年为南风输人, 北边界 11 月至次年 2 月为北风水汽输人, 其他月份为南风水汽 输出, 南边界水汽输人大于北边界水汽输出, 由此可以看出各边界水汽输送对长江流域水汽收支都有重 要影响 ${ }^{[14]}$. 对 1961-2005 年长江中下游逐月边界水汽输送和流域水汽收支做线性趋势分析(图 2), 结果发 
现: 1、2 月各边界水汽输送和水汽收支都有增加, 但都未通过显著性检验, 除东边界在 3、8、10 和 11 月 水汽输出有所增加外, 其它各边界水汽输送都出现下降, 其中 5 月份都下降显著. 5-9 月汗期, 长江中下 游南边界和西边界水汽输人都显著下降, 东边界水汽输出下降并不明显, 但北边界水汽输出下降异常显 著. 各边界水汽输送的变化造成了长江中下游地区水汽收支呈现双峰型结构, 两个波峰分别出现在 7 月 和 1 月, 波谷分别处于 4 月和 9 月. 水汽收支的逐月线性变化趋势与长江中下游冬季、夏季降水增多, 春 季和秋季降水减少相吻合.

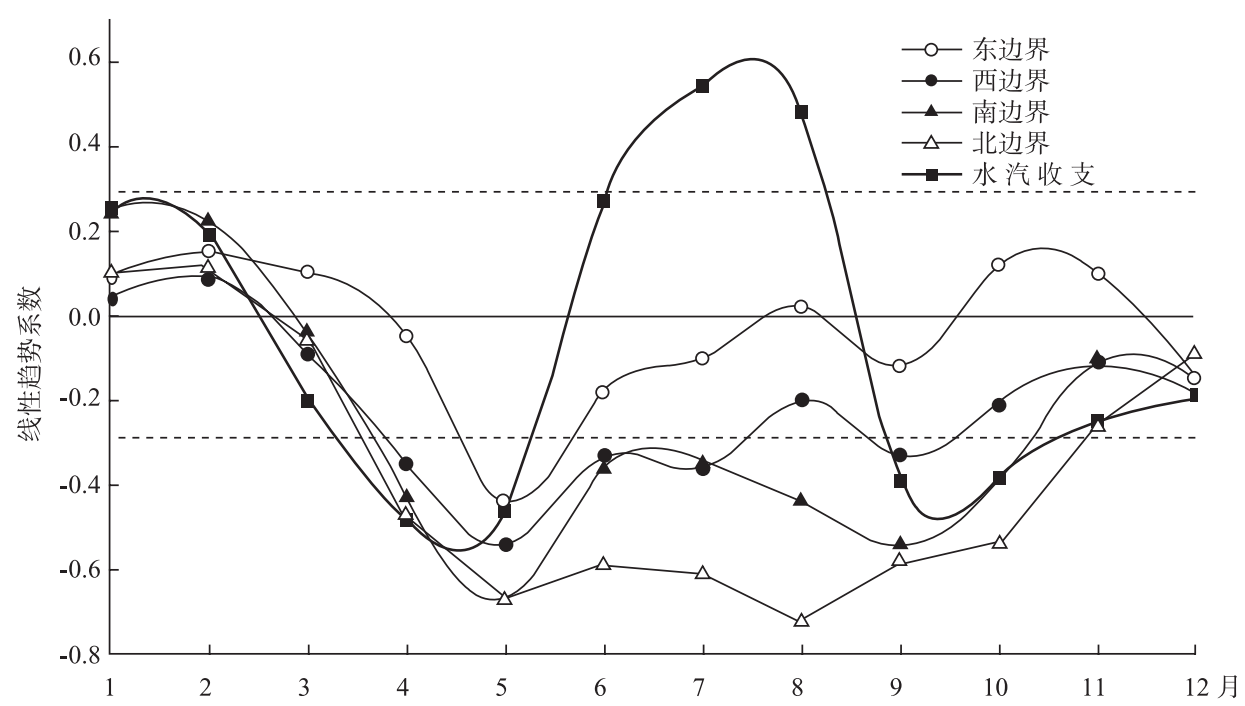

图 2 1961-2005 年长江中下游水汽输送区域边界整层水汽收支逐月线性趋势

(虚线表示通过 0.05 的显著性检验)

Fig.2 Linear trends of monthly moisture budget at the boundaries of Middle and Lower reaches of Yangtze River basin, 1961-2005(the dash lines denote the 0.05 significance level)

\section{3 长江流域水汽收支与降水的关系}

对 45 年来长江上游和中下游水汽收支与降水的趋势进行比较(表 1$)$, 结果发现: 春季、夏季、秋季, 长 江上游和中下游的水汽收支和降水变化趋势一致, 春季和秋季都表现为下降, 而夏季都为增加, 冬季上 游水汽收支和降水都下降, 而中下游水汽收支下降, 降水增加; 年水汽收支都出现下降, 上游降水下降, 但中下游降水却出现增加(图 3). 这说明长江中下游水汽收支和降水的演变趋势并不完全一致, 冬季和年 水汽收支和降水趋势相反, 水汽收支减少, 而降水却增多, 分析原因可能是长江中下游冬季温度升高, 蒸发增加, 导致冬季降水增多, 许崇育等也发现冬季长江流域蒸发在增加 ${ }^{[24]}$; 全年水汽收支下降, 而降 水增多, 是因为夏季降水增多所致, 长江中下游地区夏季降水增加, 夏季降水占全年降水的比重也不断 增加, 20 世纪 60 年代夏季降水占全年比重为 $40 \%$ 左右, 到了 90 年代比例达到 $60 \%$.

表 1 1961-2005 年长江流域水汽收支与降水的线性演变趋势 ${ }^{1)}$

Tab.1 Linear trends of moisture budget and precipitation in the Yangtze river basin

\begin{tabular}{|c|c|c|c|c|c|c|c|c|c|c|}
\hline & \multicolumn{2}{|c|}{ 冬季 } & \multicolumn{2}{|c|}{$\begin{array}{l}\text { 春季 } \\
\end{array}$} & \multicolumn{2}{|c|}{ 夏季 } & \multicolumn{2}{|c|}{ 秋季 } & \multicolumn{2}{|c|}{ 全年 } \\
\hline & 上游 & 中下游 & 上游 & 中下游 & 上游 & 中下游 & 上游 & 中下游 & 上游 & 中下游 \\
\hline 水汽收支 & $-^{*}$ & - & $-^{*}$ & $-^{*}$ & $+^{*}$ & $+^{*}$ & - & $-^{*}$ & $-^{*}$ & - \\
\hline 降水 & - & $+{ }^{*}$ & - & - & + & + & - & - & $-^{*}$ & + \\
\hline
\end{tabular}

1)+表示上升; - 表示下降; *表示通过 $95 \%$ 的显著性检验. 

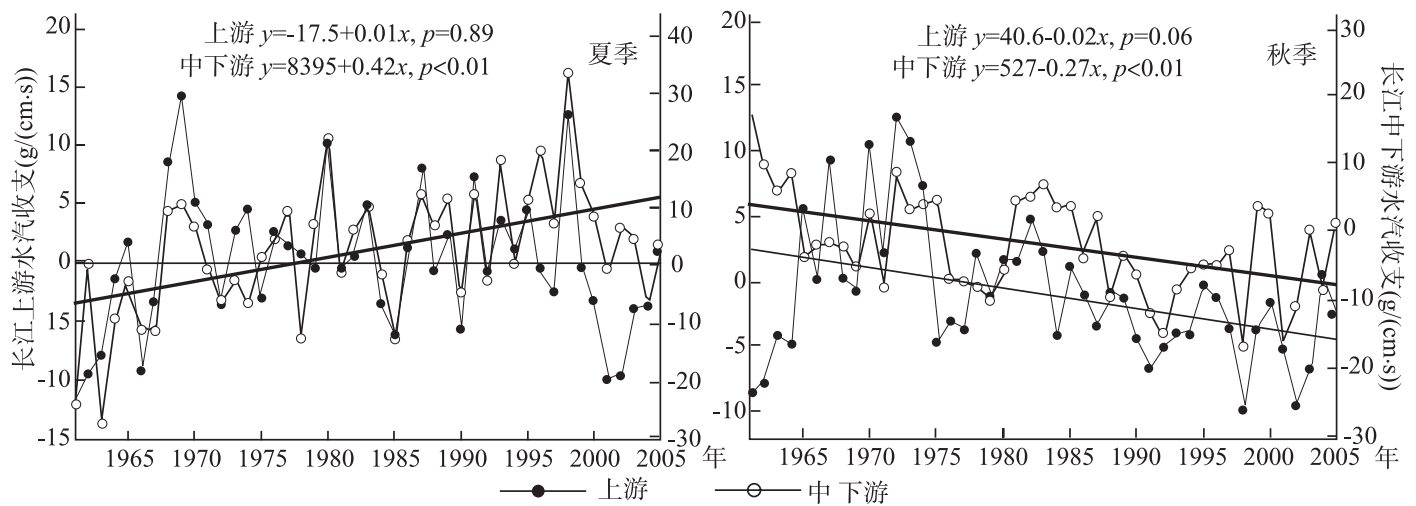

图 3 长江流域水汽收支距平的季节变化(1961-2005 年)

Fig.3 Variation of seasonal water vapor budget in the Yangtze River basin during 1961-2005

为分析水汽收支与降水的关系, 分别计算了长江上游和中下游水汽收支与同期降水的相关系数(表 2), 结果发现: 水汽收支与降水的相关系数较高，长江中下游水汽收支与降水的关系较上游水汽收支与 降水的关系要好的多, 中下游水汽收支与降水的相关系数都通过了显著性检验, 其中夏季相关系数最高, 达到 0.79 , 冬季相关系数最小, 但也达到 0.62 , 年水汽收支与降水的相关系数为 $0.70 ;$ 而上游水汽收支与 降水的关系, 除了春季和秋季相关系数较高, 通过了显著性检验, 冬季、夏季和年相关系数较低, 未通过 显著性检验. 从而可以看出, 水汽收支与长江流域降水有密切关系.

表 2 长江流域水汽收支与降水相关系数(1961-2005 年)

Tab.2 The correlation between moisture budget and precipitation in the Yangtze river basin during 1961-2005

\begin{tabular}{cccccc}
\hline & 冬季 & 春季 & 夏季 & 秋季 & 全年 \\
\hline 上游 & 0.24 & $0.40^{*}$ & 0.21 & $0.4^{*}$ & 0.12 \\
中下游 & $0.62^{*}$ & $0.59^{*}$ & $0.79^{*}$ & $0.72^{*}$ & $0.70^{*}$ \\
\hline
\end{tabular}

*表示线性关系通过 0.05 的显著性检验.

\section{4 长江流域水汽输送的变化机理}

\section{1 空中水汽分布特征}

为进一步分析长江流域水汽收支变化的原因, 对 1961-2005 年夏季整层大气水汽纬向与经向输送线 性趋势做了详细分析(图 4), 结果发现, 45 年来纬向与经向水汽输送都发生了巨大变化, 东亚地区纬向和 经向水汽输送都下降明显, 其中纬向水汽输送在黄河流域下降最显著, 而长江流域也有下降; 经向水汽 输送, 从孟加拉湾经中南半岛、华南, 一直到长江流域、华北, 都出现显著下降, 其中长江流域经向水汽 输送下降最显著, 线性倾向趋势系数达 -0.6 , 说明 45 年来, 夏季输人到中国大陆的水汽量下降显著, 这与 图 2 得出的结论是一致的. 通过对 1961-2005 年东亚上空整层大气水汽含量的线性演变趋势分析, 结果 发现夏季长江流域及其以南地区空中水汽含量显著增加, 而长江以北, 尤其华北地区空中水汽含量显著 下降; 秋季，长江流域水汽含量下降，除江北部分地区下降显著外，其它大部分地区下降都不显著，华南 地区水汽含量虽有增加，但增加也不显著(图 5). 因而，可以看出夏季，长江流域水汽通量下降，主要是 因为风速下降造成的，而与长江流域及其以南地区的空中水汽含量变化关系不大. 


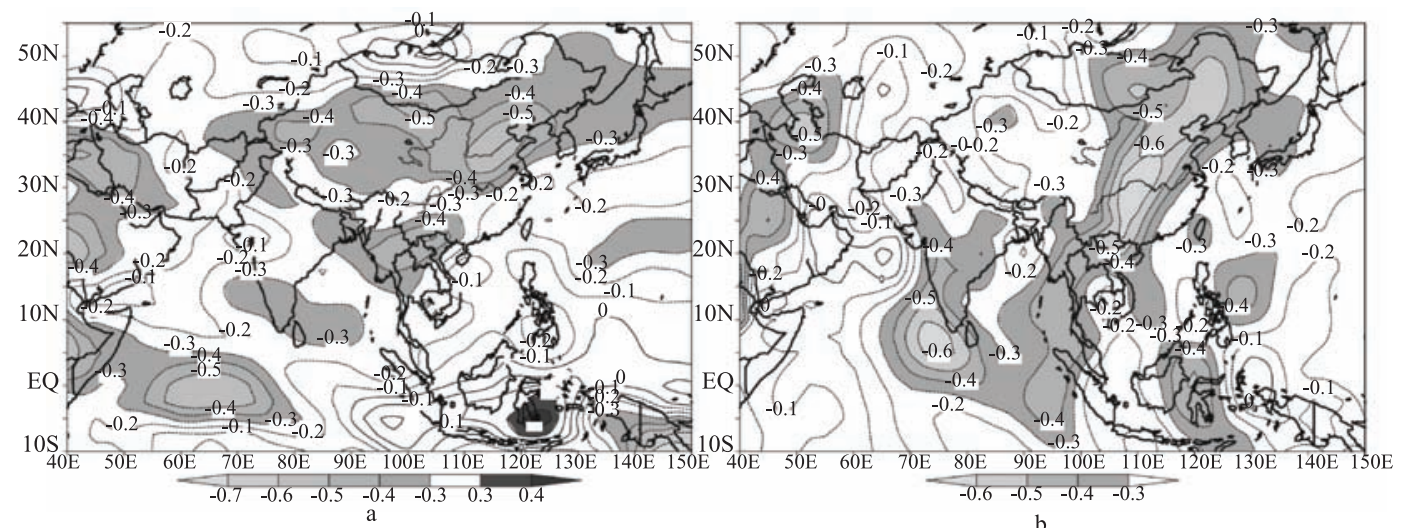

图 4 1961-2005 年夏季整层大气水汽纬向输送与经向输送线性趋势 (a: 纬向输送(阴影区表示纬向水汽输送); b: 经向输送(阴影区表示经向水汽输送))

Fig.4 Trends in summer of whole layer water vapor flux during 1961-2005 at zonal water flux(a) and meridional water flux(b)
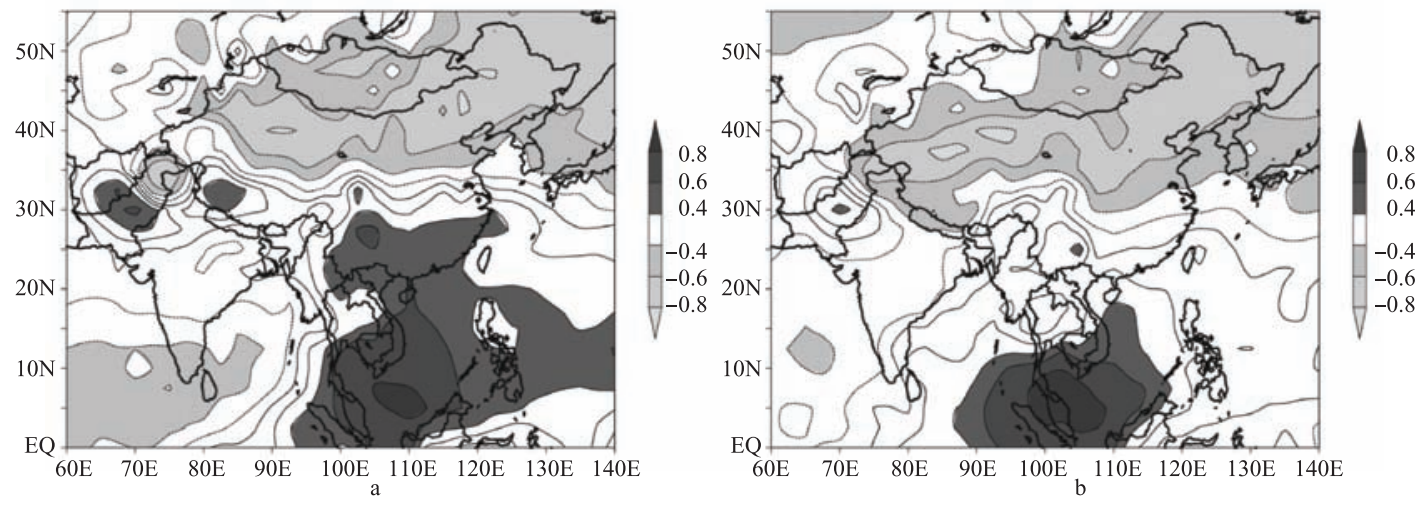

图 5 1961-2005 年夏季(a)和秋季(b)整层大气空中水汽含量的线性趋势系数空间分布

Fig.5 Trends in summer (a) and autumn (b) of whole layer water vapor content during 1961-2005

\section{2 长江流域风场和高度场变化}

从各边界水汽输送的变化也可以看出, 虽然夏季进人长江中下游地区水汽量下降, 但水汽收支还在 增加, 原因可能与北边界水汽输出下降显著有关, 即从长江中下游进人华北的水汽下降造成的. 对 1961-2005 年夏季东亚上空 $850 \mathrm{hPa}$ 和 $500 \mathrm{hPa}$ 的位势高度做线性趋势分析(图 6), 可以看出近 45 年来, 东 亚地区 $850 \mathrm{hPa}$ 和 $500 \mathrm{hPa}$ 高度场都显著增强, 从印度洋到华北线性趋势系数呈阶梯状步步抬高, $850 \mathrm{hPa}$ 位势高度线性趋势相关系数中心位于蒙古高原上空, 长江以北线性趋势相关系数多在 0.75 以上, 长江以 南多在 0.65 以下，长江以北位势高度线性增加趋势明显高于长江以南; $500 \mathrm{hPa}$ 中心位于内蒙古高原上空, 长江以北线性趋势系数也明显高于长江以南, 长江以北多在 0.7 以上, 而长江以南多在 0.6 以下. 1961-2005 年华北位势高度显著增强, 可能与近 20 年来东亚夏季风减弱有一定关系, 也影响到中国东部 地区经向水汽输送, 进人华北的水汽量明显减少. Wang 和 Yu 等 ${ }^{[25-26]}$ 分析了 1961-2002 年东亚上空大气 环流形势演变趋势，认为中国中东部上空低层大气东北风趋向增强，削弱了东亚夏季风强度，致使夏季 风难以到达华北地区，雨带多停留在长江流域，因而夏季长江中下游地区降水增多，而华北降水减少， 这个结论与我们分析的结果是一致的. 


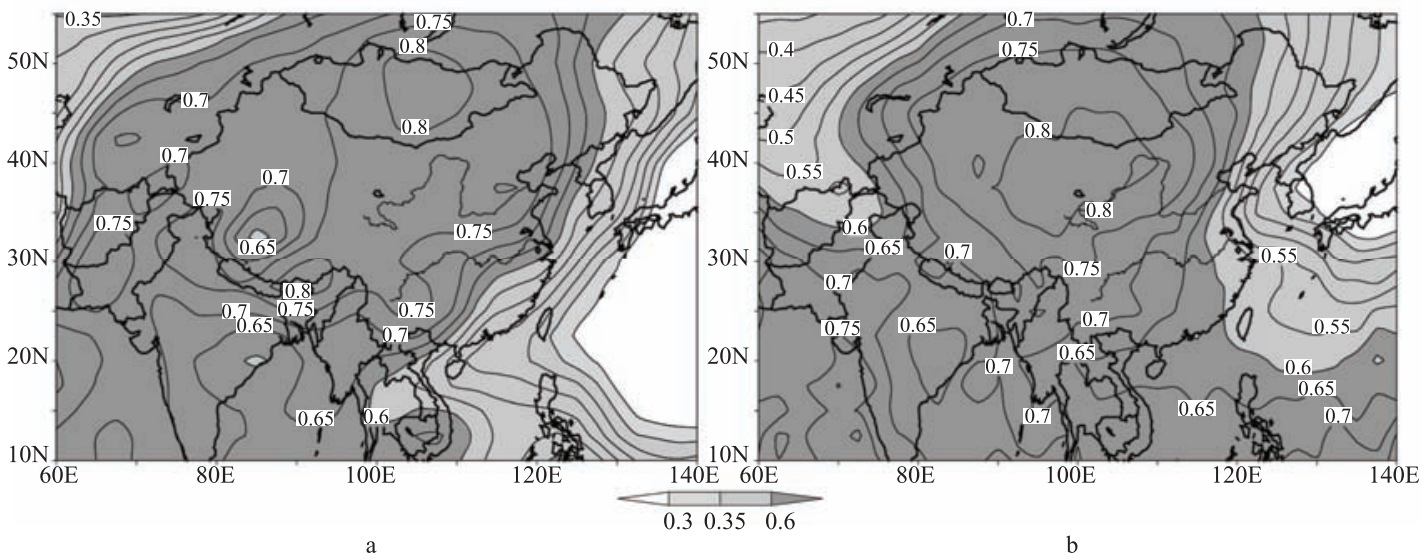

图 6 1961-2005 年夏季 $850 \mathrm{hPa}(\mathrm{a})$ 和 $500 \mathrm{hPa}(\mathrm{b})$ 高度场线性趋势分析 (阴影区表示通过 95\%的显著性检验)

Fig.6 Trends in geopotential height in summer during 1961-2005 at $850 \mathrm{hPa}$ (a) and $500 \mathrm{hPa}(\mathrm{b})$ (the contours indicate the correlation coefficient between time and the geopotential height, for which values large than 0.3 is statistically significant at the $95 \%$ confidence level)

\section{5 结论}

通过分析 1961-2005 年长江上游和中下游整层大气水汽收支的演变特征及与区域降水的关系，发现:

(1) 45 年来, 长江上游和中下游春季、秋季、冬季和年水汽收支下降，而夏季增加，上游除夏季外，都 通过了显著性检验; 中下游则只有春季、夏季和秋季通过了显著性检验，其它季节变化不显著.

(2)长江流域水汽收支与同期降水的关系非常好，而长江中下游水汽收支与降水的关系明显好于上游， 中下游水汽收支与降水的相关系数都通过了显著性检验, 其中夏季相关系数最好, 冬季最小; 而长江上 游只有春季和秋季相关系数通过了显著性检验.

(3)1961-2005 年东亚地区夏季纬向和经向水汽输送出现明显下降趋势, 纬向输送在黄河流域下降最 显著, 长江流域也有下降; 经向水汽输送, 从印度洋经中南半岛、华南，一直到长江流域、华北，都出现 显著下降，其中长江流域水汽输送下降显著，因而近 45 年来，夏季输人到中国大陆的水汽量在显著下降。 水汽输送的变化可能与夏季风减弱有关，而风场的变化又可能与位势高度场的变化有关，东亚地区 $850 \mathrm{hPa}$ 和 $500 \mathrm{hPa}$ 高度场都出现显著增强，从印度洋到华北位势高度增幅自南向北呈阶梯状逐渐抬升，长 江以北高度场线性趋势系数明显超过长江以南, 低层大气位势高度的增强, 削弱了东亚夏季风, 水汽输 送难以输送到华北地区, 多停留在长江流域及其以南地区.

(4) 长江流域水汽收支的空间差异及季节变化对流域降水产生了重要影响, 这一研究对了解长江流 域旱涝灾害的形成机理具有重要意义，也为理解当前全球变暖这一背景下长江流域水资源变化与水资源 管理有重要理论与现实意义.

致谢：中国气象局气候中心资料室为本研究提供了降水观测资料，谨致谢意！

\section{6 参考文献}

[1] 姜 夰, 施雅风. 气候变暖, 长江水灾与可能损失. 地球科学进展, 2003, 18(2): 277-284.

[2] Jiang T, Su BD, Heike H. Temporal and spatial trends of precipitation and river flow in the Yangtze River Basin, 1961-2000. Geomorphology, 2007, 85: 143-154.

[3] Zhang Qiang, Tong Jiang, Marco Gemmer et al. Precipitation, temperature and streamflow analysis from 1951 to 2002 in the Yangtze Catchment, China. Hydrological Sciences Journal, 2005, 50(1): 65-80.

[4] Su BD, Xiao B, Zhu DM et al. Trends of frequency of precipitation extremes in the Yangtze River basin, China: 1960-2003. 
Hydrological Sciences Journal, 2005, 50(3): 479-492.

[5] Zhang Zengxin, Zhang Qiang, Jiang Tong. Changing features of extreme precipitation in the Yangtze River basin during 1961-2002. Journal of Geographical Sciences, 2007, 1: 33-42.

[6] Zhang Qiang, Jiang Tong, Liu Chunling. Changing trends of water level and runoff during past 100 years of the Yangtze River (China). Asian Journal of Water, Environment and Pollution, 2006, 3(1): 49-55.

[7] Zhang Qiang, Xu Chongyu, Stefan Becker et al. Sediment and runoff changes in the Yangtze River basin during past 50 years. Journal of Hydrology, 2006, 331: 511-523.

[8] 王守荣, 朱海川, 程 否等. 全球水循环与水资源. 北京: 气象出版社, 2003: 89-101.

[9] 陈隆勋, 朱乾根, 罗会邦等. 东亚季风. 北京: 气象出版社, 1991: 49-61.

[10] 周长艳, 李跃清. 长江上游地区水汽输送的气候特征. 长江科学院院报, 2005, 22(5): 18-22.

[11] 陆渝容, 高国栋. 我国大气中平均水汽含量与水分平衡的特征. 气象学报, 1984, 42(3): 301-310.

[12] Yasunari T, Suppiah R. Some problems on the interannual variability of Indonesian monsoon rainfall. In: Theon JS, Fugono N eds. Tropical rainfall measurements. Deepak, Hampton, Va, 1988: 113-122.

[13] 苗秋菊, 徐祥德, 张胜军. 长江流域水汽收支与高原水汽输送分量“转换”特征. 气象学报, 2005, 63(1): 93-99.

[14] 赵瑞霞. 中国长江、黄河流域的水分收支与水分循环[博士学位论文]. 北京: 中国科学院研究生院, 2004.

[15] Starr VP. Direct measurement of the hemispheric poleward flux of water vapor. J Meteor Res, 1955, 14: 217-225.

[16] Chen TC. Global water vapor flux and maintenance duing FGGE. Mon Wea Rev, 1985, 113(10): 1801-1819.

[17] Chen TC, Tzeng RY. Global-scale intra seasonal and annual variation of divergent water flux. Meteorol Atmos Phys, 1990, 44 3-15.

[18] 徐淑英. 我国的水汽输送和水分平衡. 气象学报, 1958, 29(1): 33-43.

[19] 刘国伟, 崔一峰. 中国上空的涡动水汽输送. 水科学进展, 1991, 2(3): 145-153.

[20] 徐祥德，陶诗言，王继志等. 青藏高原一季风水汽输送“大三角扇型”影响域特征与中国区域旱涝异常的关系.气象学报， 2002, 3: 257-267.

[21] 陆渝蓉, 高国栋. 我国大气中平均水汽含量与水分平衡的特征. 气象学报, 1984, 42(3): 301-310.

[22] Miao QJ, Xu XD, Zhang SY. Whole layer water vapor budget of Yangtze River valley and moisture flux components transform in the key areas of the plateau. Acta Meteorological Sinica, 2005, 63: 93-99.

[23] Buishand TA. Some methods for testing the homogeneity of rainfall records. Journal of Hydrology,1982, 58: 11-27.

[24] Xu CY, Gong L, Jiang T et al. Decreasing reference evapotranspiration in a warming climate - a case of Changjiang (Yangtze River) catchment during 1970-2000. Advances in Atmospheric Sciences, 2006, 23(4): 513-520.

[25] Wang YQ, Zhou L. Observed trends in extreme precipitation events in China during 1961-2001 and the associated changes in large-scale circulation. Geophysical Research Letters, 2005, 32: L09707.

[26] Yu RC, Wang B, Zhou T. Tropospheric cooling and summer monsoon weakening trend over East Asia. Geophysical Research Letters, 2004, 31: L22212. 